\title{
A Philosophical Argument for a Bill of Rights
}

\author{
CÉCILE FABRE*
}

This article seeks to show that the rights which protect people's autonomy should be entrenched in the constitution of a democratic state. It is firmly located in egalitarian liberal tradition, as it takes for valid the following claims: (1) people have a fundamental interest in autonomy; (2) people have rights that their interest in autonomy, and the interests to which it gives rise, be protected and promoted; (3) people's respective interests in autonomy must be protected equally. The argument for a bill of rights unfolds as follows: first, it is argued that we have autonomy-protecting rights not only against private individuals but also against the state, and the meaning of having such rights against the state is explained; then it is shown that it is legitimate to turn certain autonomy-protecting moral rights into legal rights, and that doing so in the case of the rights we have against the state amounts to turning them into constitutional rights; lastly, two objections to the argument deployed earlier are countered.

Most egalitarian liberals think that individuals have a fundamental interest in autonomy, conceived standardly as the ability to frame, revise and pursue a conception of the good. ${ }^{1}$ They also claim that autonomy gives rise to other interests, such as freedom of speech or access to housing; that these interests are important enough to be protected by rights, precisely because they must be furthered in order for people to be autonomous; and that people's respective interests in autonomy should be protected equally. Most of them aver that these rights should be constitutionalized, that is, they should be entrenched in the constitution, subjected to a stringent amendment procedure and protected by the judiciary. ${ }^{2}$ Yet, surprisingly enough, none of the arguments for bills of rights that can be found in the relevant literature are satisfactory. For example, Raz claims that some rights should be entrenched in the constitution of a democratic state not because they protect fundamental interests of individuals, but because they protect fundamental elements of the public culture; his position clearly does not do justice to the importance of those interests for individuals. ${ }^{3}$ Others argue that these rights are intrinsic in democracy itself and that they must be

* Nuffield College, Oxford. I am very grateful to R. Bellamy, G. A. Cohen, John Gardner, Jeremy Horder, Sophia Reibetanz, Albert Weale, the members of the Nuffield and UCL Political Theory Workshops as well as two anonymous referees of this Journal for their numerous and incisive comments on earlier drafts of this article.

${ }^{1}$ See, e. g., Joseph Raz, The Morality of Freedom (Oxford: Clarendon Press, 1986), p. 370, and John Rawls, Political Liberalism (New York: Columbia University Press, 1993), p. 72.

${ }^{2}$ This is not a purely academic debate. Increasingly one hears arguments in favour of a bill of rights in Britain. See, e.g., Ronald Dworkin, A Bill of Rights for Britain (London: Chatto and Windus, 1990); 'It's all over for the old constitution', The Independent, 30 January 1995, p. 13.

${ }^{3}$ Raz, The Morality of Freedom, pp. 255-63. 
constitutionalized so as to protect democracy from the abolition of its own structure. But by not giving constitutional protection to those rights which are not intrinsic in democracy, they give pre-eminence to the value of democracy without convincingly arguing for it. $^{4}$

This article shares with egalitarian liberals the following claims: (1) people have a fundamental interest in autonomy; (2) people have rights that their interest in autonomy, and the interests to which it gives rise, should be protected and promoted; (3) people's respective interests in autonomy must be protected equally. Its purpose is to argue convincingly that those rights which protect people's autonomy should be entrenched in the constitution of a democratic state. It unfolds as follows. First, I argue that we have autonomy-protecting rights not only against private individuals but also against the state, and I explain what having such rights against the state means. In the next section, I argue that it is legitimate to turn certain autonomy-protecting moral rights into constitutional rights, that the democratic majority should be legally forced to respect individual autonomy. Last, in the final section, I counter two objections to the argument deployed earlier.

Three preliminary remarks are in order. First, I do not mean to imply that autonomy is the only value that the state ought to protect and promote. That my argument for bills of rights rests on the importance of individual autonomy does not deny that a similar argument can be constructed which appeals to other values, such as well-being. I choose to focus on autonomy because it is central to contemporary liberal philosophy, to which this article seeks to contribute.

Secondly, I assume that rights are interest-based, in the sense that someone has a right when an interest that she has is important enough for her to hold other people under the duty not to harm it. ${ }^{5}$ I also adopt Hohfeld's classic analysis of legal rights, and assume that it is possible to apply it to moral rights. ${ }^{6}$ Hohfeld argues that a right is a legal relation between two parties, so that for every right there is a correlative term describing the legal position of the other party in relation to the right-holder. He also argues that when we talk of someone's having a legal right, we are likely to have in mind one of the following four legal concepts: a claim-right, a liberty, a power or an immunity. Each of these four concepts has a correlative. A legal claim-right correlates with a legal duty, so that to have a claim-right is to be owed a legal duty by someone. My having

\footnotetext{
${ }^{4}$ See, e.g., John H. Ely, Democracy and Distrust (Cambridge, Mass.: Harvard University Press, 1980); Richard Arneson, 'Democratic Rights at National and Workplace Levels', in David Copp, Jean Hampton and John Roemer, eds, The Idea of Democracy (Cambridge: Cambridge University Press, 1993), pp. 118-48.

5 The definition of a right that I give here is of course inspired by Raz's definition in The Morality of Freedom, p. 166.

${ }^{6}$ Wesley N. Hohfeld, Fundamental Legal Conceptions as Applied to Judicial Reasoning (New Haven, Conn.: Yale University Press, 1919). In The Morality of Freedom, Raz claims that his analysis of rights can be extended so as to include these notions (Raz, The Morality of Freedom, p. 168, fn. 1).
} 
a legal claim-right against you that you let me go to Paris means that you are under a legal duty to let me go to Paris. A legal liberty, which is defined as the absence of legal duty, correlates with an absence of legal claim-right on the part of someone else. For me to be at the legal liberty to express myself means that you have no legal claim-right against me that I refrain from expressing myself. A legal power, which is defined as the legal ability to change a legal relation, correlates with a liability: someone's having a legal power to change a legal relation in which another person is makes that person legally liable to this relation being changed. A clear example is the legal power to make the law: if I have the legal power to make laws which affect you, it means that you are legally liable to have your legal situation changed by me through these laws. Last, having a legal immunity means being protected from changes in one's legal status, and it correlates with legal disability, or absence of legal power, in other people. The clearest example of legal immunity, which is particularly appropriate in this context, is a constitutional provision: if, say, the right to freedom of speech is constitutionally entrenched, the legislature lacks the legal power to make laws which are in breach of the right, and the right-holders have a legal (or constitutional) immunity against the legislature. ${ }^{7}$ Note that it is possible for one given right to be a cluster of several or all Hohfeldian rights.

I will therefore slightly modify Raz's standard definition of right and assume that someone has a right if and only if an interest he has is important enough to ground a duty, a liability, a disability and/or a lack of claim-right on some other person(s).

Thirdly, I shall not attempt to show that the judiciary is well equipped to protect individual rights. It is indeed necessary to distinguish the issue of competence from the issue of legitimacy. One might argue, as I shall here, that it is legitimate for judges to adjudicate on individuals' rights and yet deny that they are able to do so (for they are too conservative, they lack sufficient information about the plaintiffs, the logic of rights precludes it, etc.). Or one might argue that judges are actually competent to do so. Now, the question of competence is an institutional question. My argument is a philosophical one (hence the title of this article), in that it seeks to show that the constitutional entrenchment of rights is morally required; it therefore addresses the question of legitimacy. If it were shown that these rights, once made constitutional, could not be effectively protected by the judiciary, then a proponent of those rights would have to accept that they should not be constitutionally entrenched. But I shall set this question aside, and attempt to show that, on the assumption that the judiciary would do a good job of protecting rights, it is morally legitimate

\footnotetext{
${ }^{7}$ See Peter Jones, Rights (Basingstoke, Hants: Macmillan, 1994), p. 24; David Lyons, 'The Correlativity of Rights and Duties', Nous, 4 (1970), 45-57, pp. 50-1; Rex Martin, A Theory of Rights (Oxford: Clarendon Press, 1993), p. 30; Herbert L. A. Hart, 'Bentham on Legal Rights', in Alfred W. B. Simpson, ed., Oxford Essays in Jurisprudence, 2nd series (Oxford: Clarendon Press, 1973), pp. 198-200.
} 
and necessary to entrench certain autonomy-protecting rights in the constitution of a democratic state. ${ }^{8}$

\section{RIGHTS AGAINST THE STATE}

For someone to have a moral cluster-right to $x$ means that other people are under a moral duty, a moral disability, a moral liability, and/or that they have no claim right against the cluster-right bearer. This as such says nothing as to who exactly these people should be. Should it be the state? Private individuals? Let us set aside the case of special rights, such as the rights which arise out of promises and contracts and which characterise relationships specifically between the parties in such promises or contracts. In the case of other rights, of which autonomy-protecting rights are a subset, the following questions remain: who primarily has the moral duty to respect our moral claim-rights? Who is morally liable to our exercise of moral power-rights? Who has no moral claim-right against us so that we have moral liberty-rights? Who is morally disabled by our moral immunity-rights? It is my contention that if we take rights seriously, then the state, as well as private individuals, must stand under these complex relations with respect to our exercise of moral cluster-rights. My argument to that effect takes the following form:

(1) We all have equal rights against private individuals that they respect our autonomy. ${ }^{9}$

(2) The very same considerations of autonomy that give rise to rights against private individuals are also reasons for holding that we have rights against the state. Therefore:

(3) One cannot consistently hold that we have equal autonomy-based rights against private individuals and deny that we have equal autonomy-based rights against the state.

I assume at the beginning of this article that we have equal rights that our autonomy be respected, and I will not come back to this. There are two main reasons why we have rights against private individuals that they respect and further our autonomy. First of all, autonomy captures an essential characteristic of human beings, which distinguishes them from other beings, namely their

\footnotetext{
${ }^{8}$ For the distinction between judges' competence and legitimacy, see Martha Jackman, 'The Protection of Welfare Rights Under the Charter', Ottawa Law Review, 70 (1988), 315-38. For a distinction between institutional and moral arguments in favour of constitutional rights, see Raz, The Morality of Freedom, p. 257. Although I distinguish the question of competence from the question of legitimacy, they can be interconnected. If judges badly affect people's rights because they are incompetent to deal with them, then one might conclude that they do not have the legitimacy to adjudicate them.

9 I am aware that to use the word 'right' in the plural here is stylistically odd, and one might expect to read 'we all have an equal right against private individuals that they respect our autonomy'. However, as I do not wish to take a stance as to whether we have $a$ right to autonomy, I use the plural, so as to convey as concisely as I can the idea which this first claim expresses, to wit, that there are things we must have in order to be autonomous, such as certain freedoms and material goods, and that we have rights to them.
} 
ability rationally and morally to decide what to do with their lives, and to implement these decisions, over long periods of time, so as to lead a meaningful existence and thus develop an awareness of the kind of persons they are. ${ }^{10}$ Were we to deny that respecting and furthering people's autonomy is fundamentally important, we would thereby ignore "what is essential to being human and to being able to live a distinctly human life. ${ }^{11}$ Furthermore, individuals have an equal right that their autonomy be respected and furthered. For making their prospect for a autonomous life depend on others' benevolence deprives them of the possibility of demanding that others protect this fundamental interest of theirs. In so far as people, as a matter of fact, are not yet so educated and motivated that they would always respect individuals' autonomy, it is important to impress upon them that they must do so and/or that they cannot refrain from doing so.

Clearly, these two considerations apply to the state. Were the state not to attach fundamental importance to people's autonomy, it too would ignore what is essential to being human. Besides, in so far as there are good reasons to think that states will violate people's autonomy, there are good reasons not to make people's prospects for an autonomous life depend on the state's benevolence, and to insist that the state must protect people's autonomy.

Let us assume, for instance, that we have an interest in freedom of speech, which is derived from our interest in autonomy and which is therefore deemed important enough be protected by a right against private individuals. Such a right is a moral claim-right against private individuals which holds them under a moral duty not to prevent us from speaking. Now, if only private individuals, and not the state, were under this duty, we would weaken the right, because we would in fact allow the state to harm this interest in such a way as to crush it. The moral right to freedom of speech is also a moral liberty-right to speak freely, and here again to say that private individuals have no moral claim-right against us that we refrain from speaking and that the state does have such a moral claim-right would make a mockery of our interest in freedom of speech.

Thus, if we were content to say that only private individuals are under moral duties, disabilities and liabilities, and lack claim-rights against us, and if we did not concede that the state also stands in these relations with us, we would thereby fail to accord decent protection to those interests that we deem so important.

Here, I am touching upon the complex question of the relationship between private morality and public morality. My point is not that private morality constrains public morality and that it is possible to determine everything that the state cannot and must not do simply by determining everything that private individuals cannot and must not do. Rather, my claim is that in some cases we

10 The conception of autonomy I am sketching out here and the reasons I put forward as to why we should value it are standardly liberal. See, e.g., Rawls, Political Liberalism, p. 72; Gerald Dworkin, The Theory and Practice of Autonomy (Cambridge: Cambridge University Press, 1988).

${ }^{11}$ Jones, Rights, p. 128. 
forbid private individuals and the state from harming people on the same grounds. ${ }^{12}$ If the reason why a certain action is forbidden to a private individual is that this action violates the autonomy of someone who has not already forfeited his right not to have his autonomy violated, ${ }^{13}$ then such an action should not be allowed to the state either; it should therefore not be allowed to this person when he acts as a citizen or as a representative.

Note that some interests that we have can be harmed or promoted only by the state, and sometimes only by citizens or their representatives. For instance, my interest in elections being called at regular intervals can be promoted only by the state because only the state can call for elections at regular intervals. More generally, my interest in certain laws being passed or repealed can be furthered only by citizens and representatives. Other interests that we have will normally be promoted by the state only although, strictly speaking, they could be promoted by private individuals as well. For instance, my interest in voting could be furthered by a car owner who could drive me to the polling station. However, we expect the state to set up enough polling stations for people not to have to rely on others' goodwill.

Some of these interests are derived from autonomy, in the sense that if they are harmed, autonomy is harmed. As a result, they are important enough to be protected by rights that we have against the state. For it would not make sense to claim on the one hand that interests derived from autonomy which can be furthered by the state and by private individuals are protected by rights, while interests which are also derived from autonomy but which can be furthered only by the state, on the other hand, (or which one will expect the state to further) may not be protected by rights. Of course, it may be that these interests are not important enough to be protected by rights, as we shall see in a moment. However, that they can be furthered only by the state is irrelevant as to whether they can be protected by rights or not.

Thus, we have autonomy-protecting rights against both private individuals and the state. More specifically, we have moral rights against citizens and members of the legislature that they should protect our autonomy. So far so good. But it is worth elaborating a bit more on what having such rights against the state means exactly. There are three kinds of state agents likely to be involved in rights relationships with rights holders: state officials, who apply the law; members of the legislature, who vote on the law; and fellow citizens, who elect members of the legislature and who sometimes vote on the law in referendums. The claim that we have autonomy-protecting rights against state officials and members of the legislature is less controversial than the claim that we have such rights against citizens. And yet, we do have such a right against citizens because

\footnotetext{
${ }^{12}$ For a similar account of the links between private and public morality, see William Nelson, On Democracy (London: Routledge and Kegan Paul, 1980), pp. 100ff; and Thomas Nagel, 'Ruthlessness in Public Life', in Thomas Nagel, Mortal Questions (Cambridge: Cambridge University Press, 1979).

${ }^{13}$ This relative clause is important. If you kill someone, your interest in remaining free, which is derived from your interest in autonomy, is not important enough to claim that the state is acting in a morally wrong way if it locks you up.
} 
in a democratic regime, citizens exercise some degree of control over who gets into power and how power is exercised as well as sometimes deciding on fundamental matters by referendum. To that extent, they therefore can and must be held responsible for what their representatives and the government do and for the laws they vote for themselves. ${ }^{14}$ Indeed, it would not make sense to assert the importance of respecting individuals' moral rights and on that basis to hold private individuals and the legislature under a moral duty or disability in respect of those rights but not to hold citizens under the same moral duties and disabilities.

Note that my point is not that individuals have prima facie rights to certain goods and freedoms which are necessary for them to be autonomous, that the democratic majority (citizens and representatives) has a prima facie right to curtail these freedoms or not to provide people with those goods, and that when the rights of individuals and the right of the democratic majority conflict, the latter overrides the former. My point is that asserting that individuals have such rights against the democratic majority amounts to saying that the democratic majority does not have the right to refrain from providing these goods and to curtail these freedoms in the first instance, so that there is no conflict between the right of the majority and the rights of individuals. In other words, individuals have a given interest, such as freedom of speech; the majority has a conflicting interest, to wit, violating freedom of speech. Saying that individuals have a right against the democratic majority that it not violate their freedom of speech amounts to saying that the majority's interest in violating freedom of speech is not important enough to be protected by a power-right to do so and by a claim-right that individuals do not speak; it also amounts to saying that individuals' interest in freedom of speech is important enough to be protected by an immunity-right that it not be violated, and by a claim-right to speak.

In order to adjudicate between people's conflicting interests before rights are assigned, one needs a common metric by which to judge the relative importance of conflicting interests. ${ }^{15}$ Now, recall that I assume at the beginning of this article that we have a fundamental interest in being autonomous, that our interest in autonomy matters as much as other people's such interest and must therefore be protected equally. Note, furthermore, that our right to vote and thereby to shape the environment we live in stems from autonomy. To say that people must protect our autonomy means that they must give us the freedoms and resources we need in order to lead an autonomous life. Voting and having laws enacted

${ }^{14}$ For points along these lines, see Thomas Nagel, Equality and Partiality (Oxford and New York: Oxford University Press, 1991), pp. 84, 99-101.

15 See Jones, Rights, pp. 201-2, on the need for such a common metric, and Alan Gewirth, The Community of Rights (Chicago: University of Chicago Press, 1996), pp. 45ff., for the adoption of agency as such a common metric. Both Jones and Gewirth seem to think that this common metric must be used to adjudicate conflicts between rights, whereas I think that it should be used to adjudicate conflicts between interests so as to decide which interests are important enough to be protected by rights. (For a fuller discussion of conflicts between rights, see my 'Constitutionalising Social Rights', Journal of Political Philosophy, 6 (1998), 263-84.) 
which shape the social environment in which we further our autonomy are such resources, as is, for example, the use of our body. ${ }^{16}$

I suggest, thus, that autonomy be such a common metric. ${ }^{17}$ In assessing whether the democratic majority's interest in, say, exercising its political power to curtail freedom of movement, is important enough to assign it the power-right to do so, one has to determine whether by not allowing the members of the majority to act in this way one will render them less autonomous than the people whose freedom of movement would be guaranteed. If it turns out that not allowing them to curtail privacy will render them less autonomous, then one can conclude that their interest is important enough to justify assigning them the power-right to curtail privacy, that is, to justify holding individuals under a liability that their privacy be curtailed. If, on the contrary, it turns out that people whose privacy would thereby be curtailed would be less autonomous than citizens whose power to violate this privacy would be guaranteed, those people's interest in privacy can be said to be important enough to hold citizens under a disability to harm it.

The reason why citizens do not become less autonomous if they are allowed to harm people's autonomy than these people become if their autonomy is violated is the following. Just as we cannot make use of our body in such a way that it harms other people's autonomy, so we cannot make use of our power to vote for laws in such a way that it harms other people's autonomy. ${ }^{18}$ If using my body in pursuit of my conception of the good life involves hitting you in the stomach, it cannot be said that my interest in using my body in this particular way is important enough to be protected by a right; for I thereby retain my bodily integrity and you lose yours, and so in that brief moment you are less autonomous than I am. Conversely, if you have to refrain from using your body in such a way, you cannot say that you are less autonomous than me, because you have your bodily integrity, and so do I. Similarly, suppose you use your vote in such a way as to advance a conception of the good in the public forum, for instance, by enacting laws which forbid certain types of associations which you dislike and which I want to join. You will live according to your conception of the good, since you will be able to join the associations that you like, and you will therefore be autonomous. However, I will not be autonomous, or at the very least I will not be as autonomous as you are, because unlike you, I will not be able to join the associations that I like. As a result, your interest in making that

${ }^{16}$ Here I follow Thomas Christiano's brilliant argument in The Rule of the Many: Fundamental Issues in Democratic Theory (Boulder, Colo.: Westview Press, 1996), pp. 69ff.

17 This does not apply to arguments for bills of rights which rest on other values than autonomy. In such cases, one will have to look for a different metric.

${ }^{18}$ Clearly, if you assault me and if the only way I can defend myself is by knocking you unconscious, I am allowed to do it, thereby using my body to harm your autonomy. For in assaulting me you have forfeited your right against me that I do not use my body in such a way. Similarly, citizens and members of the legislature are allowed to use their vote to pass laws permitting certain constraints on people's autonomy, such as prison sentences. See fn. 13 for a similar point. 
decision is not important enough to be protected by a power-right, and I have an immunity-right against you that you do not make it.

If you use your vote to pass laws which are not beneficial to your autonomy but which harm mine, whether you intend it to do so or not, then your interest in having such laws enacted is not important enough to hold me under the liability that my autonomy should be restricted. For voting is a resource which we are given because it allows us to shape the environment in which we frame, revise and pursue our conception of the good life: it is justified on the ground that autonomy is important. So in cases where you do use it in such a way that it does not bear on your autonomy and nevertheless harms mine, in cases, that is, where there is a conflict between your interest in using the vote and my interest in autonomy, your interest in using it is not important enough to be protected by a power-right to use it. To sum up then, the democratic majority does not have the moral power-right to harm people's autonomy or to refrain from promoting it.

In arguing that we have autonomy-protecting rights against the state, I have drawn upon the view that we have such rights against private individuals. Note, however, that the means whereby private individuals and citizens and their representatives violate people's rights are very different: as a private individual you will violate my right to freedom of speech by silencing me, say, by interrupting me all the time, by assaulting me when I express my views; as a citizen or a member of the legislature, you will violate it by voting for censorship. As my argument so far indicates, this is the only distinction between the harm done to certain interests, such as freedom of speech, by private individuals and the harm done to these interests by citizens or representatives. And yet, this distinction is an important one, because it captures a distinction between the kind of moral rights we have against private individuals and the kind of moral rights we have against citizens and representatives. If I claim, 'I have a moral right to freedom of speech against you qua private individual,' I imply that you lack a moral claim-right against me that I do not speak, and that you are under a moral duty to let me speak; that is, you are under a duty not to assault me, not to silence me, etc. If I say, 'I have a moral right to freedom of speech against you qua citizen and representative,' I imply that you have a moral duty not to establish censorship and that you are under a disability: you should have no legal power to establish censorship. Now, recall that the right to establish a legal state of affairs is a power-right; the right to pass a specific law is therefore also a power-right. By saying that you are under a disability to establish censorship I mean that you do not have a moral power-right to establish it, and I thereby imply that I have a moral immunity-right against you that you do not establish it. I do not have such a moral immunity-right against you qua private individual. More generally, the moral cluster-rights we have against private individuals do not always contain moral immunity-rights, whereas the moral cluster-rights we have against citizens and members of the legislature always contain moral immunity-rights (as well as claim-rights and libertyrights). 
To sum up my argument so far: $P$ sometimes has an interest which, deriving as it does from his fundamental interest in autonomy, is sufficiently important to hold that $Q, R$ and $S$, as private individuals, are liable to $P$, lack a claim-right against $P$, are under a duty to refrain from acting, or/and a disability to act in ways that are contrary to that interest. The very reasons why we think that $Q$, $R$ and $S$ as private individuals stand in these relations with $P$ also warrant holding them, as citizens and/or members of the legislature, under a liability to $P$, under a lack of a claim-right against $P$, under a duty to refrain from enacting laws that violate this interest, and/or under a disability to enact such laws.

\section{FROM MORAL RIGHTS TO CONSTITUTIONAL RIGHTS}

The first step of my argument for bills of rights consisted in showing that we have autonomy-protecting rights against the state and in explaining what having such rights means. In the second step, I shall show that if we take seriously autonomy and the moral rights which protect it, we should entrench these rights in the constitution of a democratic state.

In the previous section I made a distinction between those moral cluster-rights that we have against private individuals and against the state, and those moral cluster-rights that we have against the state only. I shall make my case for the constitutionalization of these two kinds of rights separately. First, I shall argue that if we take seriously most of the moral rights protective of autonomy that we have against private individuals and the state, then we must take the view that they should be turned into legal rights. I shall then claim that if that view is correct, these moral rights should be turned into constitutional rights. Secondly, I will argue that those rights which we have against the state only and which protect autonomy should also be constitutionally entrenched.

Now, not all moral rights should be turned into legal rights, for the enforcement of those rights by the state may simply be impossible. Clear examples of such rights are moral rights to promises being kept. If I promise you to water your plants while you are away, you certainly have a moral claim-right against me that I do it. But it is not clear that this moral claim-right ought to be turned into a legal claim-right, that is, that I ought to be legally liable to pay you compensation if I fail to fulfil this promise. One might argue that it would be too difficult to have proof that I indeed made that promise to you; or that the harm you incurred through my lack of reliability does not warrant compensation; or that making me liable would degrade the character of our relationship, since trust would no longer play the same role in our lives. However, there are sometimes good reasons to turn certain moral cluster-rights into legal cluster-rights. If we take seriously autonomy, the interests it gives rise to and the moral cluster-rights which protect these interests, we must argue that there ought to be a law preventing people from violating other people's cluster-rights. As Hart puts it,

there is no incongruity, but a special congruity in the use of force or the threat of force to secure that what is just or fair or someone's right to have done will in fact 
be done; for it is just in these circumstances that coercion of another human being is legitimate.

To have a legal cluster-right against someone is precisely to have a cluster-right, recognized by the law, that this person refrain from harming the interest protected by the right. The reason why it is important that the law recognize people's rights is that without the law, these rights would be nominal only, and would offer little guarantee that the interests that they protect morally are effectively safeguarded. ${ }^{20}$ Turning those moral clusterrights into legal cluster-rights offers such a guarantee, because private individuals not only are under the legal duty to refrain from harming the interests in which the rights are grounded but they are also denied the legal power to do it, on pain of sanction. ${ }^{21}$ In so far as autonomy is of fundamental moral value, it is especially important that people should be legally unable to harm individuals' interest in autonomy and the interests it gives rise to.

I argued earlier that we have those rights not only against private individuals but also against the state and in particular against citizens and their representatives. Now, if we accept this claim and the claim that most moral cluster-rights which protect our autonomy and which we hold against private individuals and citizens should be turned into legal rights against private individuals, we must hold the view that these moral cluster-rights should also be turned into legal cluster-rights against citizens and their representatives. That is, citizens and members of the legislature, when acting in the public forum, should not be legally allowed to violate those rights either. If we take seriously autonomy and the rights which protect it, driving a wedge between what people legally cannot and must not do qua private individuals and what they legally cannot and must not do qua citizens and members of the legislature seems arbitrary. Just as we think that there ought to be legal constraints on private individuals' exercise of their autonomy in the private forum, there ought to be legal constraints on citizens' and their representatives' exercise of autonomy in the public forum. The constitution and, more specifically, the bill of rights thus serve as such legal constraints on citizens and members of the legislature in that they hold them under legal duties to respect individual rights and in that they legally prevent them from violating these rights. Simply saying that moral rights should be turned into legal rights is not enough, because it does not provide any legal guarantee that citizens and members of the legislature will respect those rights by refraining

${ }^{19}$ H. L. A. Hart, 'Are There Any Natural Rights?' Philosophical Review, 64 (1955), 175-91, p. 178.

${ }^{20}$ See Martin, A System of Rights, pp. 83 and 85.

${ }^{21}$ I do not wish to suggest that legal rights are as a matter of fact always backed up by sanctions. In fact, as Raz has shown, some legal rights, for instance some of the legal rights we have against state officials, are not backed up by sanctions (see Joseph Raz, Ethics in the Public Domain (Oxford: Clarendon Press, 1994), pp. 240-1). I will not address here the question whether these rights are really legal rights. (See Jones, Rights, pp. 39-44, for comments on this issue.) 
from enacting laws which violate those rights, or by enacting the laws necessary to implement those rights.

Recall that earlier I argued that there is a distinction between the kind of moral rights we have against private individuals and the kind of rights we have against citizens and representatives: the moral rights which protect autonomy are not always moral immunity-rights when held against private individuals, but are always moral immunity-rights when held against citizens and members of the legislature. Similarly, there is a difference, which mirrors this distinction, between private individuals on the one hand and citizens and members of the legislature on the other hand, with respect to the kind of legal constraints that are placed on them. When we say that private individuals should not be legally permitted to harm someone, we do not always mean that this person has an immunity-right against them, because what private individuals are legally disabled from doing is not always the changing of a legal or moral relation in which that person stands. For example, my not being legally permitted to assault you if you express subversive views against capitalism does not amount to a legal disability to change a legal relation in which you stand. (By contrast, my being legally unable to marry you without your consent does amount to a legal disability to change your legal status, namely the legal status of being unmarried.)

The legal constraints placed on citizens and representatives by the constitution are different in that they always constitute a legal disability to change a legal relation in which people stand. Conversely, constitutional rights always ground a lack of legal power in citizens and members of the legislature and are therefore always immunity-rights. Turning a moral right into a constitutional right means that the interest protected by the moral right is important enough legally to disable citizens and members of the legislature from enacting laws which violate those moral rights.

Note that the argument works for those rights which we have against citizens and members of the legislature and which we do not have against private individuals. The interests protected by those rights, to wit autonomy and the interests which are derived from it, are the same as the interests protected by the rights we have against private individuals, and there is therefore no reason to think that they should not be afforded the legal protection that other rights are afforded, by way of the constitution. It would indeed seem arbitrary to say that such rights should be enforced legally when held against private individuals, citizens and members of the legislature, but that they should not be so enforced when held against citizens and members of the legislature only.

So far, I have argued for the constitutionalization of autonomy-protecting rights: I have not argued for giving individuals the power to vindicate them in court. Indeed, the two issues are logically distinct: one can have a legal or a constitutional right without having the power to vindicate it in courts. ${ }^{22}$

\footnotetext{
${ }^{22}$ In France, for example, citizens have constitutional civil, political and social rights, and these rights are upheld by the Constitutional Council, which has the power to strike down laws in breach
} 
However, there are very good reasons for giving such power to people. The acknowledgement that certain things cannot be done, or must not be done, to people justifies the assignment of rights, and also justifies the assignment of the power to go to court. In particular, if one is committed to the claim that autonomy is a fundamental interest of people, it makes little sense, as a matter of principle, to deny people the power to vindicate in courts the legal and constitutional rights which protect those interests. ${ }^{23}$ Furthermore, if individuals have rights against the legislature, the latter should not be judge in conflicts it has with rightsbearers, and these conflicts should be settled by an independent party. The courts are such a party and it therefore makes sense to entrust them with this task.

In arguing for bills of rights, I do not mean to imply that entrenching individual rights in the constitution will prevent all violations of rights. If a democratic majority is bent on violating rights, no legal or constitutional provision will hinder it. As Stephen Holmes puts it, 'a preceding generation cannot prevent a succeeding generation from saying: "No more freedom!" But this incapacity does not imply that predecessors have no right or reason to design institutions with an eye to making such decision difficult. ${ }^{24}$ I wholly agree with him here, and contend that for that reason constructing an argument for the legitimacy of making such decisions difficult is important. This presupposes that the democratic majority should not always be trusted. I believe that such distrust is warranted in the light of violations of rights by democratic regimes. This is not to say, though, that democratic majorities should be radically distrusted. For if these majorities were unable ever to support individual rights, it is unlikely that bills of rights would find any long-term support. ${ }^{25}$ A certain amount of distrust is the basis for such arguments, and as long as people are not educated to have respect for other people's rights, such a distrust is warranted. Whether people can be so educated is another issue which I will not address here.

Relatedly, one might think that if, in order for a bill of rights to be respected and therefore to fulfil its role, people have to support the rights that it protects, then it is unclear why we should have it. If people are motivated to respect individual rights, then institutional tools, such as a bill of rights, which

(F'note continued)

of those rights. However, citizens do not have a right to lodge complaints to the Council. In most countries where rights are protected by the constitution, though, rights-holders are endowed with such a power. As a result, discussions about constitutional rights are nearly always discussions of American-style judicial review.

23 As a matter of practice, it may well be the case that the courts, for various reasons, are incompetent to protect rights, be they constitutional or legal. As I said in the introduction to this article, I refrain from discussing these institutional issues.

24 Stephen Holmes, 'Precommitment and the Paradox of Democracy', in Jon Elster and Rune Slagstad, eds, Constitutionalism and Democracy (Cambridge: Cambridge University Press, 1988), pp. 195-240, at p. 226.

25 Jones, Rights, pp. 222-6; Jeremy Waldron, 'Rights and Majorities: Rousseau Revisited', in Jeremy Waldron, Liberal Rights: Collected Papers 1981-1991 (Cambridge: Cambridge University Press, 1993), pp. 392-420, at p. 406. 
aim at constraining people to respect those rights seem unnecessary. ${ }^{26}$ However, this objection against arguments for bills of rights does not hold, because it is not true that people respect a bill of rights, indeed any law, if and only if they wholly agree with its content. People may think that they ought to accept a law or a bill of rights simply because it is there and because the cost of overturning it outweighs the cost of having to put up with it. More generally, it is possible for people to support a political system under which they are prevented from doing certain things, for instance violating individual moral rights, which they would do if they were not so prevented. ${ }^{27}$

\section{OBJECTIONS AGAINST BILLS OF RIGHTS}

Objections against bills of rights are numerous and it is impossible, within the scope of this article, to address them all. In this section I shall examine two claims against the argument I have sought to make in favour of constitutional rights, both of which challenge it at its very heart.

\section{A Right-Based Objection Against Constitutional Rights}

Here I wish to tackle the kind of objection which has been put forward by Jeremy Waldron and James Allan. ${ }^{28}$ According to them, for someone to want individual rights to be part of the constitution means that she thinks that her own formulation of rights is better than any other and for that reason should be entrenched in the constitution so that it is difficult to change, and that she does not trust what other people could do with rights in the future. They reject this combination of self-assurance and mistrust on the ground that there is an inherent contradiction between the constitutionalization of rights in the name of individual autonomy and what such constitutionalization presupposes, to wit, our distrust of the individuals we pretend to respect. The very fact that we assume that people are autonomous, have dignity, are able to think and act morally and therefore are bearers of rights should prompt us to trust them as 'bearers of political responsibilities', ${ }^{29}$ and should convince us that the fact that they disagree with us about rights does not imply that they are 'either simpletons

26 This objection was put to me at a seminar in Oxford in April 1995.

27 See Nagel, Equality and Partiality, p. 88. In saying that people often support a law for prudential reasons or because they respect the law as such, and not because they agree with its content, I am not committed to saying that they are right to support it for those reasons. I am simply saying that in so far as there may not be any genuine support for the rights protected by the bill in the absence of a bill, and in so far as people might nevertheless desist from resisting the bill of rights, arguing for such a bill does make sense.

${ }^{28}$ Jeremy Waldron, 'A Right-Based Critique of Constitutional Rights', Oxford Journal of Legal Studies, 13 (1993), 18-51; James Allan, 'Bills of Rights and Judicial Power - A Liberal Quandary', Oxford Journal of Legal Studies, 16 (1996), 337-52.

${ }^{29}$ Waldron, 'A Right-Based Critique of Constitutional Rights', p. 28 
or rogues, ${ }^{30}$ or that they will harm us when we exercise what we deem to be our rights. We should therefore not place them under a legal disability by entrenching one particular conception of rights in a bill.

However, there is no inconsistency in saying that human beings are able to think and to act morally on the one hand, and that they quite often commit appalling acts on the other hand. It is precisely because they are moral beings that we are appalled by what they can do. By arguing that we should trust that people will assume political responsibilities and will not seek to crush rights, Waldron and Allan fail to see that saying that people are worthy of respect, and therefore have rights, does not entail that they will always respect other people's rights. Consequently, it is not absurd to entrench rights in the constitution, in order to protect the fundamental interests they encapsulate against the majority's attempts at harming them. Moreover, the fact that someone wants individual rights to be protected in a bill of rights does not mean that she never trusts her fellow citizens, whatever the circumstances are. Waldron and Allan unfairly depict such a person as a dogmatist who is never willing to admit that she may be wrong and who is always ready to dismiss other people's views. That is an inaccurate picture, and Waldron and Allan's line of attack thus fails.

\section{Democracy-Based Objections Against Constitutional Rights}

I have said very little about judges so far, and it might be objected that I have not shown convincingly enough why we should entrust them, rather than the legislature, with the protection of individual rights. Before I tackle this objection, it is worth re-stating my argument for bills of rights and showing exactly what the link is between this argument and the claim that judges rather than MPs should adjudicate these rights.

My argument goes like this: if we think that we have autonomy-protecting rights against the state as well as against individuals, and if we think that these rights should be turned into legal rights against private individuals, then we must think that these rights should be turned into legal rights against the state as well. Such legal rights against the state are constitutional rights. Thus, I am not directly putting forward an argument to the effect that the judiciary is more likely to protect these rights than the legislature. Similarly, when one argues that certain moral rights held against private individuals should be turned into legal rights, one is not arguing that the judiciary is more likely to protect these rights than private individuals are. One is saying, in both cases, that in so far as private individuals and the democratic majority are likely to violate autonomy-protecting moral rights, these rights should be turned into legal and constitutional rights, so as legally to disable duty-bearers from violating them.

\footnotetext{
29 Waldron, 'A Right-Based Critique of Constitutional Rights', p. 28

${ }^{30}$ Waldron, 'A Right-Based Critique of Constitutional Rights', p. 28. See also Allan, 'Bills of Rights and Judicial Power - A Liberal Quandary', p. 345.
} 
This, of course, gives us strong reasons for allowing the courts to give redress to someone whose rights have been violated, be it by the state or by private individuals. ${ }^{31}$

This partly, but not completely, answers the objection that an argument is needed to entrust judges with the protection of rights. It does not completely answer it, because my argument for bills of rights rests on an analogy between rights we have against private individuals and rights we have against the state. And in some cases, as I have noted earlier, this analogy does not work.

To start with, a statute turning private individuals' moral duties and disabilities into legal duties and disabilities will always be more detailed than a constitution laying down citizens' and representatives' legal duties and disabilities. As a result, judges will have less scope for interpretation in the first case than in the second case. In other words, the objection would go, it is false to say that the role of judges when they adjudicate legal rights against private individuals is the same as their role when they adjudicate constitutional rights. In the latter case democracy is seriously undermined whereas in the former it is not, or much less so.

The objection has some force, but it does not undermine my argument. Judges, including constitutional judges, are subject to strict rules of reasoning and argument. Their decisions, which they must justify, are constrained by previous decisions, and in that sense they are under more constraints than the legislature. The image of judges changing at one stroke of the pen entire aspects of the public culture is just that: an image. It may be that constitutional judges have more leeway than other judges, but this does not entail that they can do whatever they want with the constitution. Nor does this imply that the resulting loss of power for the democratic majority is such that bills of rights are altogether undesirable. In order to reject bills of rights on that basis one has to show that democracy has pre-eminence over autonomy-protecting rights. Earlier, I put an argument to the contrary.

I have noted above that the analogy between private individuals and the state does not always work. In particular, there are things that the state is allowed to do and which private individuals are not (such as putting people in prison), and vice versa. This, it could be said, undermines my position, because these issues - when the state can legitimately exercise its power and when it cannot - are essentially controversial and ought to be settled by citizens themselves, through a democratic procedure. ${ }^{32}$

This objection stems, I think, from a wider concern about the nature of rights and indeed of autonomy itself. As many have argued at length, these are very contested concepts which can be interpreted in very different ways by different members of the polity. This could either support a claim to the effect that there should not be bills of rights at all, or support a claim that there could be a bill

${ }^{31}$ I do not wish to imply that no argument per se can be deployed in favour of entrusting the judiciary with individual rights. I gave some idea of what such arguments may be at the end of the second major section.

${ }^{32}$ This point was put to me by Richard Bellamy. 
of rights provided it is the result not of an independent argument of the type I present earlier but of a freely negotiated agreement between citizens. The first claim is advanced by Jeremy Waldron, while the second claim is advanced by James Tully, Richard Bellamy, Dario Castiglione and others. ${ }^{33}$ I shall first examine Tully and Bellamy's claim, then Waldron's.

Tully, Bellamy et al. do not reject bills of rights. They claim instead that, in political communities characterized by a multiplicity of belief and a disenchantment with values once held to be universal, bills of rights, and more generally constitutions, cannot be seen as the expression of a pre-political normative order. They must instead embody norms that are 'politically constructed and legitimated by those who are to submit to them' ${ }^{34}$ These norms are constructed through a democratic procedure in which all citizens participate.

The proceduralist objection against bills of rights stems from the claim that people disagree about rights. It is problematic in two respects. First, its solution to the existence of disagreements, namely giving precedence to the right to political participation, seems self-defeating. If, as these authors say, there are good reasons to think that people disagree about the requirements of autonomy, there are good reasons to think that one of these requirements, to wit, political participation itself, is subject to such disagreements. In fact, people (politicians, citizens, lobbyists, not merely academics) do disagree as to what rights political participation involves. Some argue that women and minority groups should be given special representation rights, while others are adamant that this is not a correct reading of the right to political participation; some would like to give greater scope to decision making by referendum, while others fear that this would open the door to the most extreme expressions of populism. One could accumulate examples, but it is clear that giving pre-eminence to the right to political participation over other rights will not do.

Secondly, and perhaps more importantly, the objection misses what is at issue when one argues for bills of rights the way I have. One should distinguish between two very different questions: (1) Given that autonomy is a fundamental moral value, what is the most just constitution? (2) Given that autonomy is a fundamental moral value, and given that people deeply disagree about what rights it yields, if any, what is the best constitution $?^{35}$

${ }^{33}$ See Waldron, 'A Right-Based Critique of Constitutional Rights'; James Tully, Strange Multiplicities (Cambridge: Cambridge University Press, 1995), p. 30; Richard Bellamy, 'The Political Form of the Constitution: The Separation of Powers, Rights and Representative Democracy', Political Studies, 44, Special Issue (1996), 436-56; Richard Bellamy and Dario Castiglione, 'Constitutionalism and Democracy - Political Theory and the American Constitution', British Journal of Political Science, 27 (1997), 595-618; and 'The Communitarian Ghost in the Cosmopolitan Machine: Constitutionalism, Democracy and the Reconfiguration of Politics in the New Europe', in Richard Bellamy, ed., Constitutionalism, Democracy and Sovereignty: American and European Perspectives (Aldershot, Surrey: Avebury, 1996), pp. 111-29.

${ }^{34}$ Bellamy, 'The Political Form of the Constitution: The Separation of Powers, Rights and Representative Democracy', p. 455.

35 Andrew Mason's unpublished paper, 'Imposing Liberal Principles', helped me formulate this distinction. 
Objections to bills of rights are aimed at those who seek to address the first question, like myself, as if they were addressing the second question, and in that sense they miss the point. For one might very well be committed to the claim, put forward earlier, that the most just constitution is one which includes a bill of rights, the content of which is settled through a philosophical argument, and agree that, in the presence of deep disagreements between people as to what rights we have, the best constitution is one which does not protect them at all.

Waldron's objection to the kind of argument for bills of rights I set out earlier is very different to the proceduralists' in that he rejects bills of rights altogether, whereas they reject the view that bills of rights embody pre-political, philosophically argued for, values. In Waldron's eyes, bills of rights violate democracy by disabling legislators. Indeed, the constitution must usually be amended by a super majority, with the effect that citizens are unlikely to be able to amend the bill of rights; secondly, in many countries, the interpretation of the constitution is entrusted to the judiciary and not to the legislators themselves, with the effect that judges in fact revise the constitution, through changing their interpretation of it.

As to the main reason why we should not harm democracy by adopting bills of rights, it is set out as follows. There is a deep connection between democracy and rights:

Both ideas represent people as essentially agents and choosers, with interests of their own to protect and, in their dignity and autonomy, as beings who flourish best in conditions that they can understand as self-government. The modern theory of democracy represents individuals not only as blind pursuers of self-interest, but as having the capacity to engage in thought and principled dialogue about the conditions under which everyone's interests may be served. ${ }^{36}$

Engaging in principled dialogues with one's fellow citizens about important issues such as rights is all the more important as there are deep disagreements about rights:

Any theory of rights will face disagreements about the interests it identifies as rights, and the terms in which it identifies them. Those disagreements will in turn be vehicles for controversies about the proper balance to be struck between some individual interest and some countervailing social consideration. ${ }^{37}$

In other words, if we believe in rights and in the ideal which underlies them, to wit, the ideal of autonomy, we should believe in the ideal of democracy, and we should therefore not advocate a bill of rights.

Waldron's objection against any bill of rights stems from the claim that people disagree about rights. In that sense, it is vulnerable to the same criticisms I raised against the procedural view of bills of rights. But let us assume that Waldron is right that the existence of disagreements about rights bedevils any argument for a bill of rights. People, he claims, must have a say in those disagreements

${ }^{36}$ Waldron, 'A Right-Based Critique of Constitutional Rights', p. 38. My emphasis.

${ }^{37}$ Waldron, 'A Right-Based Critique of Constitutional Rights', p. 30. 
and they can have it only if there are no constraints on majority rule, only if democracy is not crushed. Going through democratic procedures is the only way, according to him, in which disputes about rights can be settled, and in fact the only way to do justice to people's autonomy. His objection, if correct, goes to the heart of my argument for a bill of rights in that it appeals to its very first premiss, to wit, the importance of the value of autonomy. I do not think that it is correct though. For, as I shall now show, it is not true that bills of rights are always undemocratic and, even when they are, Waldron's commitment to autonomy should lead him to accept them.

As we have seen, Waldron claims that should rights be constitutionally entrenched, it would destroy democratic participation. Indeed, according to Waldron, more than 50 per cent of the vote is usually required to amend the constitution and judges can strike down laws passed by the legislature and thereby (sometimes) modify the constitution. As a result, citizens do not have a say in issues concerning rights: citizens cannot amend the constitution easily, and their representatives cannot pass laws which violate individual rights as laid down in the constitution. In Waldron's view, a bill of rights, for that reason, is always undemocratic. The question, then, is whether democratic participation according to majority rule is such a crucial component of democracy.

There are several ways of defending the use of a simple majority rule, but one of the most powerful seems to me to be May's. According to May, any decision-making procedure in a democracy must meet the four following requirements. ${ }^{38}$ It must be decisive, it must not favour one voter over another in the final counting (each vote is to count equally), it must not favour one outcome over another, and it must be positively responsive, that is, if no one has a preference over whether policy A or policy B should be implemented, except one person who thinks that A should be implemented, then A should be implemented. The first is a requirement that any decision-making procedure must meet, whatever the type of regime, and is only for that reason a requirement of democracy: it would not make sense to have a decision-making procedure whereby decisions could not be reached. Both the second and third requirements encapsulate the view that people are equally valuable and that they should be conceived of as moral agents to whom equal respect is due. The second is required because democracy is that regime where people must have an equal opportunity to have a say in the way society should be run. The third is required because people's preferences about the way society should be run should not be discriminated against in the political forum.

May demonstrates that majority rule is the only decision-making procedure that meets those requirements. If a super-majority were required, or if a minority were required, the procedure would not be positively responsive and the poll

\footnotetext{
${ }^{38}$ Kenneth May, 'A Set of Independent Necessary and Sufficient Conditions for Simple Majority Decision', Econometrica, 10 (1952), 180-4. For an account of several arguments defending majority rule, see Robert Dahl, Democracy and its Critics (New Haven, Conn.: Yale University Press, 1989), pp. $138 \mathrm{ff}$.
} 
would be biased towards the status quo and towards change in the status quo respectively. The third and fourth requirements would thus be violated. If unanimity were required it would be unlikely that anything would be done, which would violate the first requirement; and since the only consideration that matters for deciding which preference will win is the number of votes for that preference, irrespective of who expresses it, the second requirement is met.

Clearly bills of rights which are interpreted and enforced by the judiciary violate the second and third of these requirements. Indeed, allowing judges to make those decisions amounts to not being neutral between individuals, since the decisions of the judges, because they are made by judges, are favoured over the decision of citizens. Allowing a minority of citizens or of their representatives to settle the issues, by way of a super-majority requirement for amendment (which gives this minority the power to veto changes desired by the majority) amounts to favouring the status quo and thus to not being neutral between policies. Now, the crucial questions are whether a democrat must always think that these two requirements must be respected for a decision to count as democratic, and whether, if the answer is 'yes', a democrat is always committed to respecting them even when not respecting them might prevent democracy from being harmed.

However, these requirements must sometimes be violated in order for the regime to count as a democracy. A democrat may believe in the ideal of democracy, which may consist solely in respecting these two requirements, on the ground that people and their preferences should be treated equally when votes are counted. Or he may subscribe to a broader conception of democracy whereby certain rights and freedoms must be guaranteed to individuals in order for a regime to count as a democracy. In the first case, not respecting these two requirements may sometimes be the only way of protecting an institutional realization of that ideal, or at least of protecting it better. Allowing the judiciary to strike down laws voted by parliament may violate the requirement that the procedure should be neutral towards citizens; asking for an amendment procedure based on a super-majority or making it difficult for the whole people to amend the constitution may violate the requirement of neutrality between policies. But if that ideal is what matters to the democrat, she must accept the claim that decision-making procedures which do not respect those requirements are sometimes preferable to decision-making procedures which respect them, because they promote democracy better than procedures which respect those two requirements. Indeed, they make sure that people remain able, in the future, to have a say in the way their society should be run. And if a democrat is committed to anything surely she must be committed to the continued existence of democracy.

In the second case, it may be that the only way to protect these other components of democracy is to violate these two requirements. There is no reason to believe that the latter should always override the former. On the assumption that people are autonomous and therefore ought to have a decisive say in the way their society is run, that is, ought to live in a democracy, it seems 
less important to stick to these two requirements than to secure the conditions under which people can form their preferences about the way their society should be run, by guaranteeing them the rights to freedom of expression, freedom of association, freedom of movement.

I have thus shown that bills of democratic rights, that is, of rights which are not only autonomy-protecting but also democracy-protecting, are not undemocratic. As a result, it is not true that these bills of rights harm autonomy. In fact, the foregoing remarks suggest that, on the assumption that one must take into account disagreements about rights, bills of rights secure the conditions under which these disagreements can be settled and in turn protect autonomy. ${ }^{39}$

Bills of non-democratic rights, that is, of rights which need not be respected for a regime to be a democracy, are clearly undemocratic. It is not clear though that Waldron should reject them for this reason. For even if these bills of rights crush political participation, they do not thereby violate people's autonomy. Saying that they do so presupposes that political participation is the best expression of the value of autonomy, and therefore that the right to political participation, understood as the right to have one's preferences satisfied if one happens to be in the majority, overrides all the other rights. Waldron does not provide any argument to that effect. And yet, an argument is needed. For there are other rights which also encapsulate this value, such as the right not to be killed, the right to privacy, the right to a decent income, etc. These rights might be said to override the right to political participation. And it may be that the importance of the former rights justify constraints on the exercise of the latter, by way of a bill of rights. In the earlier sections, I precisely sought to provide an argument to that effect.

\footnotetext{
${ }^{39}$ Waldron objects to that point and argues that entrenching procedural (or, in my exposition, democratic) rights in the constitution will necessarily lead to entrenching substantive rights, on two grounds. First, the same values underpin both kinds of rights, so that it will be very difficult to keep procedural considerations apart from substantive ones. Secondly, people value certain procedures because they think that they yield better outcomes, so that entrenching any procedural principle will amount to entrenching substantive principles (Waldron, 'A Right-Based Critique of Constitutional Rights', pp.40-1). Waldron's objection is problematic in three respects. First, I agree that considerations about individual autonomy require forming a view about both democratic participation and, say, certain distributive policies. But I do not see why by taking a stance on the former, the judiciary will be led to take a stance on the latter. That the underlying value is similar does not imply that outcomes are at stake when procedures are in issue. Secondly, we need not value political participation for the stated reason: we may value it because it gives everyone the chance of having a say about the way society should be run, irrespective of what we think people's (other) rights are. It is therefore far from clear that entrenching a particular procedure amounts to entrenching a substantive view of rights. Thirdly, if constitutionally entrenching any procedure is undemocratic and therefore unacceptable, it logically follows that there should be no constitution at all. Waldron nowhere addresses this rather obvious implication. But if he thinks that a constitution is desirable, he has to explain where we draw the line between enough and too much substance, and why we stop short of entrenching individual rights. Yet if he thinks that there should not be a constitution, he has to show that a democratic regime without any constraints whatsoever would be more protective of individual autonomy than any other alternative.
} 
To conclude, Waldron's autonomy-based objection against bills of rights fails.

\section{CONCLUSION}

In this article, I have sought to show that if we are committed to the claim that individual autonomy is important enough to be protected by rights which must be distributed equally, then we must be committed to constitutionalizing these rights, so as legally to constrain the democratic majority to respect them. My argument was philosophical, in that it did not rest on a claim that judges are institutionally better placed than the legislature to protect individual rights. I first assumed that one has rights against private individuals that protect one's autonomy only to the extent that in exercising one's autonomy one does not prevent other people from exercising theirs. I then argued that if we take this assumption seriously, it follows that citizens and representatives' interest in exercising their autonomy in the public forum is important enough to be protected by the power-right to do so only if in doing so they do not prevent us from exercising our autonomy in such a way that we would not be as autonomous as them. I then claimed that just as we think that private individuals should be legally forced to respect those rights, we must agree that citizens and their representatives should be legally constrained to do so, by way of a bill of rights. Finally, in the last section, I rejected some objections against bills of rights. In doing so I distinguished the question of the most just constitution from the question of the best constitution given widespread disagreement about autonomy and rights. This article stemmed from the recognition that the first question is largely ignored in the literature and it sought to answer it. 